\title{
Relationship between Anxiety in Second Language Learning and Motivation Orientation: The Case of Young Filipino Learners
}

\author{
Juland Dayo Salayo \\ Philippine Normal University - Manila \\ University of Santo Tomas - Manila \\ jdsalayo@ust.edu.ph
}

Arceli M. Amarles, PhD

Philippine Normal University - Manila

DOI: http://doi.org/10.36892/ijlls.v2i2.237

\begin{tabular}{|c|c|}
\hline $\begin{array}{l}\text { Received: } \\
\text { 7/04/2020 }\end{array}$ & $\begin{array}{l}\text { Abstract } \\
\text { This present study attempted to investigate the status of language anxiety and }\end{array}$ \\
\hline $\begin{array}{l}\text { Accepted: } \\
\text { 29/05/2020 }\end{array}$ & $\begin{array}{l}\text { motivation orientation of the young Filipino learners of English and how these } \\
\text { constructs are related to one another. To address these research goals, a } \\
\text { quantitative approach was employed using Liu and Cheng's (2014) Factor } \\
\text { Loadings for three-Component Solution for the Anxiety and Jin, Jiang, Juan, }\end{array}$ \\
\hline $\begin{array}{l}\text { Keywords: } \\
\text { language anxiety, } \\
\text { motivation, second } \\
\text { language learning, } \\
\text { young Filipino learners }\end{array}$ & $\begin{array}{l}\text { Zhang, Liang and Xie's (2013) motivation in language. Participated by } 39 \\
\text { Grade } 3 \text { pupils from a premier basic education school in the province of Cavite, } \\
\text { these instruments were simplified and translated to their first language (L1) to } \\
\text { suit the understanding of the young learners of English. Results showed that } \\
\text { the respondents are highly motivated in learning the second language, but the } \\
\text { 'general anxiety in English class' is evident on one hand. These two significant } \\
\text { factors showed strong correlation between anxiety and 'negative evaluation' } \\
\text { and motivation. On the other hand, there is a significant negative correlation } \\
\text { of both 'anxiety in self-confidence in speaking English' and 'general anxiety } \\
\text { about English class' to language motivation. Among the components of } \\
\text { motivation, only 'learning situations' is considered to be a predictor of } \\
\text { students' assessed anxiety. Findings suggest that motivation needs to be } \\
\text { sustained in order to build positive second language learning; otherwise, } \\
\text { anxiety may threaten the dynamics of learning processes which impedes their } \\
\text { learning in English as a second language. }\end{array}$ \\
\hline
\end{tabular}

\section{INTRODUCTION}

In learning the second language (L2), teachers usually complain about students who are unmotivated which can be manifested through their undesirable behaviors like boredom, lack of appropriate feedback (Nunan, 2011), and even awkward classroom silence (Yu, 2016). These behaviours appear to be very challenging on the part of the teachers because these involves affective factors which influence language learning (Liu \& Cheng, 2014; Tahernezhad, Behjat. \& Kargar, 2014). As a result, teachers exert lots of effort in order to activate learning motivation, including its sustainability to defeat negative feedbacks in the process of learning (Nicholson, 2013; Wu, 2010). Some of those important obligations of the teachers in sustaining students' enthusiasm include designing and employing apposite teaching strategies and applying appropriate instructional materials which are student-centered (Elashhab, 2020). These are evident in the growing number of significant literature on motivation and anxiety in acquiring the second or foreign language (Tsai \& Chang, 2013). 
Primarily, motivation generally measures the successful attempt in learning new language as it activates and sustains the target goals (Pintrich \& Schunk, 2002, cited in Lian Wong, 2012). Because of motivation, the quality to face and overcome challenges is confidently employing the acquired language skills in the authentic learning space outside the classroom (Nunan, 2011). Interestingly, motivation, mirroring the socio-psychological standpoints, can even heighten the level of power in the furtherance of second language learning (Horwitz, Horwitz\& Cope, 1986; McIntyre \& Gardner, 1994; Belmechri \& Hummel, cited in Tahernezhad, Tahernezhad, Behjat \& Kargar, 2014) because of its promises that move any individual to positive engagement in the learning tasks until the goals are achieved successfully (Chastain, 1988, cited in Tahernezhad, Tahernezhad, Behjat \& Kargar, 2014). With this, motivation does not require any concrete support to demonstrate and verify its impact to effective learning as it already gains its respect to have positive influence in second or foreign language acquisition (Nicholson, 2013). True enough, motivation is one of the most significant predictors not only in acquiring the second or foreign language, but generally in developing and enhancing "knowledge and skills" as part of education progress. For that matter, learners are expected to perform better than those who are not invigorated and reinforced (Thomas Baby, 2020, p. 88).

Language anxiety, on the other hand, pertains to the state of discomfort and apprehension or even the fear produced by any intimidating occurrence in the learning space which obstructs to the production, retention and acquisition of the new language such the learners' L2 (Tahernezhad, Behjat \& Kargar, 2014). This destructive connection to language learning can even worsen the students' state of motivation towards language achievement (Lian Wong, 2012). These language anxieties are well attributed to several factors such as learner's degree of difficulty to new language, and their personal discernment on that language. These are even worsened by the learner's perception toward language demand on perfectionism and their phobia of public speaking; the worst case is the stressful language classroom engagement (Young, 1991, cited in Zheng, 2008). In another study, different anxiety indicators were identified in the presence of the primary learning components including the students, the teachers and pedagogical practices. With the interactions of these three forces in language learning, anxiety increases because of their misconceptions, misunderstanding, and misbeliefs on their personal engagement to learning, classroom instructions and interactions and language assessment (Young, 1991, cited in Zheng, 2008). In an unfortunate situation, teachers and their classroom practices can add anxiety in language classrooms which are demonstrated by their "beliefs about language teaching, the manner of error correction, the level of perceived support, and the teaching style" (Zhang \& Zhong, 2016, p. 29).

\section{LITERATURE REVIEW}

Studies on motivations were identified with several indicators such as age, sex, culture and beliefs, and language proficiency (Dy and Muñoz, 2017; Kormos and Csizer, 2008; Ozturk, 2014). Showing the details, Ozturk's (2014) 'Students' Attitudes and Motivation for Learning English at Dokuz Eylul University School of Foreign Languages" investigated the relation between university preparatory students' attitudes toward learning English and their language motivation. The results show that there are significant positive relations between learning English and their language learning motivation. Additionally, it has been found that both their attitudes and their language learning motivation vary significantly related in terms of some factors like age, sex, and language level. Similarly, a study conducted by Kormos and Csizer (2008) titled "Age-related Differences in the motivation of learning English as a Foreign Language: Attitudes, Selves, and Motivated Learning Behavior" indicating age groups such as secondary school pupils, university students, and adult language learners had varying 
motivation behavior as secondary was interested in cultural products while both university and adult learners were into international posture. This study had an interesting note about the discrepancy between students' high level of motivation and their low level of proficiency. Those students who managed to be highly motivated would not mean that they exerted sufficient effort and energy in language learning.

Looking at the adult language learners, the study of Lucas, et al. (2011) revealed that the foreign students who participated in the study experienced language anxiety in learning English in the country. This anxiety specifically reflected in their overall fear toward negative language judgment from their peers and their teachers. In the end, this led to their high anxiety in the production of the target language. Similarly, Gopang, Bughio, \& Pathan (2015), who investigated Malaysian tertiary students' language anxiety, revealed the detrimental effect of the anxiety resulting to less motivated students. Understanding Filipino ESL tertiary learners' reaction to language anxiety and fear of negative evaluation, a study conducted by Mamhot, Martin, \& Masangya (2013) showed that the identified respondents displayed neutral reaction leading to the almost zero-level of language anxiety. Additionally, this study showed an exemption to respondents' worries on "committing mistakes in English class" with their commitment to their responsibility in language learning.

In addition, the study of Dy and Muñoz (2017) about "Motivation and Beliefs of Learners of Chinese as Foreign Language" pointed out that the participants' learning is integrative because of their interest in Chinese culture, in traveling, and in building friendship. Thus, these variables served as the source of developing language motivation. They viewed the second language as a challenging language to learn but still most of them believed that constant repetition and practice would enable them to speak the language well.

Regardless of the different study results, arguments and perspectives on the nature, roles, influences and relations of language anxiety and motivation in the second language learning, still many studies have continued to identify relationship of language motivation (Wang, 2008) and language anxiety as vital in L2 learning results (Liu \& Cheng, 2014; Tsai \& Chang, 2013; Waseem \& Jibeen, 2013) to strengthen their roles in the second language acquisition. The previous represents language achievements while the latter symbolizes "tension, apprehension, nervousness, and worry" (Horwitz, Horwitz \& Cope, 2013 cited in Tsai $\&$ Chang, 2013, p. 125). While these two are in contrasting roles in the learning dimensions, they maintain their direct influence to one another as shown in both motivated and unmotivated and assertive and apprehensive language learners (Gardner, Day \& MacIntyre (1992 cited in Liu \& Cheng, 2014; Yan and Horwitz, 2008 cited n Liu \& Cheng, 2014). This is further supported by Krashen's affective filter which states that as motivation decreases, (Shinge, 2005 ) the level of anxiety increases; both however, play together effectively across age groups (Gardner, 1991 cited in Shinge, 2005).

For instance, Liu (2012) found out that more than half of the participants' responses reflected different degrees of learner anxiety where learning motivation was among the 33 Foreign Language Classroom Anxiety Scale (FLCAS) items that appeared to have the highest correlation with foreign language anxiety. In another study by Jain and Sidhu (2013) which attempted to determine the relationship between anxiety, attitude and motivation of tertiary students in learning English as a second language indicated that there is a negative but significant relationship in learning English as a second language between the main variables among the respondents. But interestingly, respondents with low proficiency in language have higher and significant relationship in attitude and motivation than high proficiency students.

Giving weight to the relation of the two toward Second Language Acquisition (SLA), Khodadady \& Khajavy (2013) identified language anxiety and motivation among Iranian learners as the basis for the development of a foreign language achievement model through the utilization of Foreign Language Classroom Anxiety Scale (FLCAS) and Language Learning 
Orientations Scale (LLOS). The results showed that motivation and the less self-determined types of external motivation are positively related to language anxiety while intrinsic motivation and identified regulation were negatively related to language anxiety. The application of the structural equation modeling showed that both anxiety and motivation significantly predict the English achievement of the language learners within an Iranian context.

Supporting this study, $\mathrm{Wu}$ (2010) found out that most of the participants have expressed a favorable attitude toward language achievement; however, they also revealed their high level of anxiety in the language classroom which was reported to have adverse effects on the learning of a second language. Thus, it was emphasized that the language instructors have a challenging task to accelerate the language learning of their students. Accordingly, one way is to teach students how to learn more effectively and efficiently which could be achieved through high motivation orientations.

In another study, Hashwani (2008) found out that tertiary students had higher level of extrinsic than intrinsic motivation and that anxiety varies according to student's condition and specific circumstances. Tertiary students had strong desire to learn English in order to gain future achievements. In relation, Liu and Chen (2015), with the participation of high school students, found that the level of extrinsic motivation was high but their language anxiety fell in moderate level. They also proved that significant negative correlation existing between language motivation and anxiety which suggests that when student is less motivated they would likely have high level of anxiety.

Contrary to the previous results, the study of Gardner, Lalonde, Moorcroft, and Evers (1987) on "Second Language Attrition: The Role of Motivation and Use" found out that language anxiety is negatively associated with foreign language motivation. Anxiety as a secondary factor of foreign language self-confidence was related to self-confidence gained as a result of perceived communicative competence. Therefore, lack of anxiety is seen a predictor of FL self-confidence found among motivated learners.

Although much has been researched about motivation and anxiety, there is a limited literature related to the assessment of the language anxiety and motivation types among young learners of English in the Philippine context. Most foreign researches have focused on secondary and tertiary education, but comprehensive studies for younger learners are not given much attention (Jin, et al, cited in Jin, Jiang, Zhang, Yuan, Liang, \& Xie, 2014). It is of great interest to focus on young learners since teaching them is a very challenging consideration which has become an expanding activity across the globe (Asia Society, 2009; European Commission, 2008 as cited in Jurisevic \& Pizorn, 2013); thus, it is imperative that young learners' motivation and anxiety levels must be taken into consideration as they are significantly correlated to foreign language achievements (Masgoret \& Gardner, 2003 as cited in Jurisevic \& Pizorn, 2013).

Thus, this study was conducted to explore both anxiety and motivation in the learning of the second language and to identify their relationship as reflected on motivation types and the respondents' language anxiety in terms of speech and negative evaluation; self-confidence; and general anxiety. Specifically, this study attempted to answer the following questions:

1. What is the assessed language anxiety of Grade 3 pupils in terms of:

a. speaking / communication anxiety;

b. fear of negative evaluation; and

c. self-confidence in speaking English?

2. What motivates the Grade 3 pupils in learning language as reflected on the following motivation types:

a. intrinsic;

b. immediate; 
c. learning situation;

d. social responsibility;

e. individual development; and

f. information medium?

3. Is there a significant relationship between the Grade 3 pupils' anxiety in terms of speech and negative evaluation, self-confidence, and general anxiety and what motivates the young learners in learning English as reflected on motivation types?

\section{Theoretical Framework}

\section{Language Learning Anxiety}

Accordingly, language anxiety is caused by the learners' previous experiences that bring detrimental effect to the learners' language knowledge and the processes of language acquisition; hence, this occurrence may produce a serious case of language apprehension (Gardner, cited in Lovato, 2011). For Horwitz, Horwitz and Copre (1986, cited in Hidayati, 2018, p. 96), this psychological construct is "described as a feeling of tension, fearful, uneasiness, or worried that emerged due to a number of activities taking place in a foreign language class".

To assess the language anxiety of the respondents, this present study applied to Lui and Cheng's (2014) three-factor Foreign Language Classroom Anxiety Scale (FLCAS) which was originally created by Horwitz, et al (1986, cited in Waseem \& Jibeen, 2013). These factors include speaking or communication anxiety, fear of negative evaluation, and self-confidence.

\section{Motivation in Second Language Learning}

Contrary to language anxiety, language motivation is a significant construct that builds positive second language acquisition (Chang, 2006); with that, it invites more scholars and researchers to further investigate its impact to the success of English learning. Indeed, Gardner (cited in Lovato, 2011) emphasized motivation as an expression of desire to learn the target language, together with the positive feedback to successfully acquire it. Two commonly identified types of motivation, integrative and instrumental, were popularized by Gardner and Lambert, but this present study explored more specific types that were introduced by Yihong, Yuan, Ying and Yan (2007). From the original seven (7), this study adapted the following six (6) subscales:

1. Intrinsic interest. It is a form of appreciation or fondness of the target language, e.g. "I like to learn English."

2. Immediate Achievement. It is the desire to learn the target language in order to achieve acceptable results in exams, e.g. "I want to learn English because I want to pass the exam."

3. Learning situation. It is a motivation of the learner to learn English because of the pressure or influence by the learning environment like their peers, e.g. "I learn English because my classmates are better than me."

4. Social responsibility. It is another form of language motivation where learners express the desire of learning the target language to combine harmonizing the family and putting the country in order, and emphasizing individual's responsibility to fulfil social expectations, e.g. "My parents will be proud of me if I do speak well in English."

5. Individual development. It is the learning of English in order to increase one's own ability and social status in future development; it is a "sense of achievement," e.g. "A learned person should learn English."

6. Information medium to attain other academic subjects, e.g. "For me, learning 
English would be of help to widen my knowledge not just in English but also in other subjects."

The above types may be generally categorized into two types of motivation. According to Yihong, Yuan, Ying and Yan (2007), the types such as immediate achievement, individual development and information medium are classified under instrumental orientation since they are qualified to the definition of Gardner and Lambert (1972 as cited by Tsai \& Chang, 2013). Instrumental motivation entails "language learning for more immediate or practical goals" ( $p$. 26). On the other hand, integrative motivation is often associated with intrinsic interest, and used to refer as learning the language holistically. It occurs when learner does something to experience inherently satisfying result (Snowman \& Biehler, 2003) like language achievement. Social responsibility may be instrumental and cultural while learning situation is neither instrumental nor cultural as it is part of the expanded learning situational level provided by Dornyei (1994, as cited in Yihong, Yuan, Ying and Yan, 2007).

Mahadi \& Jafari (2012) further emphasizes that motivation is a very important and effective factor in the field of learning language. Thus, the language teachers and lecturers should discover, realize, and pay attention to the personality of their students especially by being aware of their motivation, its high importance, and its types. They should also realize and get familiar with the character as well as the personality of each student. Afterwards, according to that specific personality type, they should identify and recognize the form of motivation relating to that and perform it in their teaching process. In this case, they can have practical, useful, and effective language classroom in addition to a positive outcome in their teaching context.

\section{METHODOLOGY}

\section{Participants}

The participants of the study were 39 Grade 3 pupils of the selected primary school in the province of Cavite. Maintaining the ethics of the study, necessary authorization permits and consents were arranged between the researchers and the school administrators, class adviser and the respondents' parents.

\section{Instruments}

Again, this study utilized Liu and Cheng's (2014) Factors Loading for ThreeComponent Solution for the Anxiety to assess their language anxiety. From the original 33 items, this study considered only 20 items that could suit the participants as young learners. The sub-scale is divided in three Speech Anxiety and Fear of Negative Evaluation (1-8); SelfConfidence in Speaking English (9-12) and General Anxiety (13-20).

To address the second problem regarding the respondents' motivation, this study used the Motivation Scale which was used by Jin, Jiang, Juan, Zhang, Liang and Xie (2013) in their study titled "Motivations and Expectations of English Language Learning among Primary School Children and Parents in China." This research tool was translated to the respondents' first language (L1), Filipino, to establish better understanding. Then, the terms were divided into seven sub-scale: intrinsic ( 5 items); learning situation ( 2 items); informative medium (2 items); individual development (4 items); social development (3 items); immediate (1 item). This 17-item was taken from the 23-item questionnaire presented in the said study because they were classified according to motivation types as categorized by Yihong, Yuan, Ying, and Yan (2007).

Both instruments for language anxiety and motivation used a 3-point Likert Scale: 1 as Agree; 2 as Disagree; and 3 as Undecided. Since the participants were young (9-10 years old), 
only three choices were given for each item to preserve the validity and reliability to the questionnaires (Jin, et al., 2013).

\section{Data Analysis}

Data were analysed using descriptive statistics. To measure what motivates the participants to study English and to assess their apprehensions, means and Standard Deviation (SD) were employed. To determine the role of language anxiety in terms of speaking, confidence and language anxiety in general to achieving second language learning through motivation types exist among Grade 3 pupils, the Multiple Linear Regression was employed using IBM SPSS Software.

\section{RESULTS AND DISCUSSION}

This section presents the descriptive statistics of the pupils' language anxiety and second language motivation according to their types.

\section{Assessed Learning Anxiety}

Table 1. Descriptive Statistics of the assessed language anxiety

\begin{tabular}{lccc}
\hline Assessed language anxiety & N & Mean & Std. Deviation \\
\hline Speech Anxiety And Negative Evaluation & 39 & -.3077 & 5.22723 \\
\hline Anxiety on Self-Confidence In Speaking English & 39 & -1.2051 & 3.04510 \\
\hline General Anxiety About English Class & 39 & .9744 & 3.89661 \\
\hline Valid N (listwise) & & & \\
\hline
\end{tabular}

Table 1 shows the assessed language anxiety of the 39 Grade 3 students for all three components, including speech anxiety and negative evaluation, self-confidence in speaking in English, and the general anxiety about English class. Generally, the students do not agree that they have an anxiety on speech anxiety and negative evaluation $(\mathrm{M}=-.3077, \mathrm{SD}=5.22723)$. Likewise, students do not agree as well that they have an anxiety on self-confidence in speaking English $(\mathrm{M}=-1.2051, \mathrm{SD}=3.04510)$. However, the students believed that they have a general anxiety about English class $\mathrm{M}=.9744, \mathrm{SD}=3.89661$ ).

Looking at the data, it reveals that majority of the participants show high confidence in speaking or communication skills using English as a second language even if they have apprehension, worries and discomfort in their English class. Hence, these may result into a better appreciation and understanding to English as a second language which can further improve their performance in class. Nevertheless, the respondents' anxiety in their English class proves that other classroom tasks and materials, except speaking activities, are not meeting the demand of the learners especially in building anxiety-free learning space.

The results, however, have a contrasting data from Alico's (2015) study using the Foreign Language Classroom Anxiety Scale (FLCAS) where 68 participants from minority group in the Philippines showed a moderate to high level of language anxiety in almost all of its types such as communication apprehension, text anxiety, fear of negative evaluation and classroom anxiety. This quantitative data were supported by qualitative measures such challenges in classroom tasks that further develop anxiety including the assessment, and the perceived judgment on their competence and efficiency. Using the same instrument (FLCAS) and the Language Strategy Survey of Cohen, Oxford and Chi (2001, cited in Lucas, Miraflores and Go, 2011, p. 106), the authors have similarly found out that the respondents of their study also showed "a feeling of anxiety" in learning English which could be predicted by their 
difficulties in language learning. It was identified, however that the learners could overcome this anxiety by capitalizing on other types such as vocabulary strategy, speaking strategy and translation strategy. Results on the general anxiety in English class is also proven in the study of Tsai and Chang (2013) where respondents were negatively affected by the traditional classroom teaching, teacher-centered, that produced lots of pressure.

Motivations in Learning English Language

Table 2. Descriptive Statistics of motivations in learning English language

\begin{tabular}{llll}
\hline & $\mathbf{N}$ & Mean & Std. Deviation \\
\hline Intrinsic & 39 & 4.2308 & 1.44115 \\
\hline Learning Situations & 39 & 1.1282 & 1.17383 \\
\hline Social Development & 39 & 1.2564 & 1.68145 \\
\hline Informative Medium & 39 & 1.4872 & 1.18925 \\
\hline Individual Development & 39 & 3.0769 & 1.99189 \\
Immediate Need & 39 & 0.8462 & 0.53991 \\
\hline Valid N (listwise) & 39 & & \\
\hline
\end{tabular}

Table 2 shows the types of motivation that supports the students in learning English language. As shown in Table 2, Intrinsic Motivation greatly influences the students in learning the English language achieving the mean of 4.2308 ( $\mathrm{SD}=1.44115)$; it is followed by Individual Development $(\mathrm{M}=3.0769, \mathrm{SD}=1.99189)$. Having been intrinsically motivated, data show that the respondents' absence of speech anxiety and negative evaluation comes from within. Hence, motivation to learn their second language is heavily influenced by their personal desire to improve their skills in English.

With the positive value of the corresponding mean: Informative medium $(\mathrm{M}=1.4872$, $\mathrm{SD}=1.18925)$, Social Development $(\mathrm{M}=1.2564, \mathrm{SD}=1.68145)$, Learning Situations $(\mathrm{M}=$ $1.1282, \mathrm{SD}=1.17383]$, and Immediate Need $(\mathrm{M}=.8462, \mathrm{SD}=.53991)$, the identified factors also affect the students' motivation in learning the English language. True enough, motivation shows an influence in learning the language as all types work positively in achieving the learning goals. These prove that the respondents are interested in English language as affected by their personal choice, their environment or the needs that arise. Therefore, results imply that learning agents including the teacher, the classroom, the activities and instructional aids play significantly in achieving positive language learning.

However, determining which of these factors affect the speech anxiety \& negative evaluation, self-confidence in speaking English language, and their general anxiety about English class will be determined by Regression analysis (see results under Research Question 3.)

Using Gardner's Attitude/Motivation Test Battery (AMTB), Wimolmas (2013) found that the participants composed of 30 first year college students have high motivation in both instrumental and integrative with the mean of $4.35(\mathrm{SD}=0.56)$ and $3.94 \quad(\mathrm{SD}=0.63)$, respectively, which further proves that motivation is undoubtedly instrumental in the furtherance in the learning of English; hence, it serves basis in designing more significant school activities that create positive learning environment with the highlight to proficient language use. Nicholson (2013) has similar result where intrinsic factor is contributory in enhancing the level of the learners' motivation in foreign language classroom. Specifically, intrinsic motivation is said to be highly influenced by teachers' effort in choosing and in 
preparing instructional aids and classroom activities to address the interest and needs of the learners relevant to L2 learning. Giving attention to intrinsic factor is also helpful in building the learners' confidence which can be done in different ways such as teachers' expression of trust, praise, and encouragement among others (Dornyei, 1994, cited in Nicholson, 2013).

Relationship between the Grade 3 pupils' anxiety in terms of speech and negative evaluation, self-confidence, and general anxiety and what motivates the young learners in learning English as reflected on motivation types

Table 3.1. Tests of Normality

\begin{tabular}{lccc}
\hline & \multicolumn{3}{c}{ Shapiro-Wilk } \\
& Statistic & Df & Sig. \\
\hline Speech Anxiety And Negative Evaluation & .929 & 39 & .016 \\
\hline Self Confidence In Speaking English & .797 & 39 & .000 \\
\hline General Anxiety About English Class & .914 & 39 & .006 \\
\hline Intrinsic & .593 & 39 & .000 \\
\hline Learning Situations & .710 & 39 & .000 \\
\hline Social Development & .863 & 39 & .000 \\
\hline Informative Medium & .482 & 39 & .000 \\
\hline Individual Development & .529 & 39 & .000 \\
\hline Immediate Need & .297 & 39 & .000 \\
\hline
\end{tabular}

a. Lilliefors Significance Correction

Table 3.1 shows the normality test conducted among the variables. Due to the small sample size $(\mathrm{N}<50)$, Shapiro-Wilk Test was used. From the table, it can be seen that the variables are assumed to be normality distributed $(p<.05)$. In addition from table 5 (Model Summary), the Durbin-Watson statistics (closer to a value of 2) detect no presence of autocorrelation. This, therefore, allows the researcher to use a parametric test to test the relationship between the assessed language anxiety and the students' motivation in learning English language.

Due to the limitation of sample size $(\mathrm{N}=39)$, the analysis was conducted by performing a bootstrapping technique with the following specifications: (i) the sampling method is simple; (ii) the number of samples is 2000; (iii) 95\% confidence interval level; and (iv) Bias-corrected and accelerated $(\mathrm{BCa})$ confidence interval type.

Table 3.2. Relationship between the Speech Anxiety \& Negative Evaluation and students' motivation in learning English language

\begin{tabular}{lcccccc}
\hline $\begin{array}{c}\text { Assessed Language } \\
\text { Anxiety }\end{array}$ & $\mathbf{N}$ & $\begin{array}{c}\text { Speech Anxiety } \\
\text { and Negative } \\
\text { Evaluation }\end{array}$ & $\begin{array}{c}\text { Bootstrap for } \\
\text { Pearson } \\
\text { Correlation }\end{array}$ & $\begin{array}{c}\text { BCa 95\% } \\
\text { Confidence } \\
\text { Interval }\end{array}$ & $\begin{array}{c}\text { BCa 95\% } \\
\text { Confidence } \\
\text { Interval }\end{array}$ \\
$\begin{array}{c}\text { Lotivation in } \\
\text { Learning English }\end{array}$ & $\mathbf{N}$ & Sig. (1-tailed) & Bias & Lower & Upper \\
\hline Intrinsic & 39 & .366 & -.009 & .132 & .557
\end{tabular}




\begin{tabular}{|c|c|c|c|c|c|c|}
\hline \multirow[t]{5}{*}{$\begin{array}{l}\text { Pearson } \\
\text { Correlation }\end{array}$} & $\begin{array}{l}\text { Learning } \\
\text { Situations }\end{array}$ & 39 & .633 & -.004 & .443 & .765 \\
\hline & $\begin{array}{l}\text { Social } \\
\text { Development }\end{array}$ & 39 & .357 & -.008 & .005 & .666 \\
\hline & $\begin{array}{l}\text { Informative } \\
\text { Medium }\end{array}$ & 39 & .076 & .006 & -.315 & .446 \\
\hline & $\begin{array}{l}\text { Individual } \\
\text { Development }\end{array}$ & 39 & .184 & .021 & -.317 & .576 \\
\hline & Immediate Need & 39 & .132 & $-.001^{b}$ & $-.393^{b}$ & $.521^{\mathrm{b}}$ \\
\hline
\end{tabular}

a. Unless otherwise noted, bootstrap results are based on 2000 bootstrap samplesa

b. Based on 1914 samplesb

Table 3.2 shows that there is a positive correlation between the speech anxiety \& negative evaluation and students' motivation in learning English language. In particular, there is a strong positive correlation between learning situation and speech anxiety \& negative evaluation $(r=.633)$. This means that a more exposure to learning situation increases the speech anxiety and negative evaluation. It has been established that there is a weak relationship between intrinsic motivation and speech anxiety and negative evaluation $(r=.336)$, and social development and speech anxiety and negative evaluation $(r=.357)$. However, the relationship of speech anxiety and negative evaluation to informative medium $(r=.076)$, individual development $(r=.184)$, and immediate need $(r=.132)$ is very weak (negligible). While limited literature do not directly link the relationship of speech anxiety and negative evaluation and language motivation, the study of Jain and Sidhu (2013) generally state that anxiety shows negative impact on motivation, together with another variable in their study, the attitude, among the 60 first year tertiary students who participated using Gardner and Smythe's AMTB Survey and semi-structure interviews. Further, the results also revealed that while the level of anxiety increases, the level of motivation decreases as influenced by their state of consciousness every time language tasks are given. As a proof, one of the participants claimed that such anxiety becomes an obstruction to achieve a better competence in English language.

Table 3.3. Relationship between the Self-Confidence in Speaking English and students' motivation in learning English language

\begin{tabular}{lllcccc}
\hline \multicolumn{1}{c}{$\begin{array}{c}\text { Assessed Language } \\
\text { Anxiety }\end{array}$} & $\mathbf{N}$ & $\begin{array}{c}\text { Anxiety in Self } \\
\text { Confidence in } \\
\text { Speaking } \\
\text { English }\end{array}$ & $\begin{array}{c}\text { Bootstrap for } \\
\text { Pearson } \\
\text { Correlation }\end{array}$ & $\begin{array}{c}\text { BCa 95\% } \\
\text { Confidence } \\
\text { Interval }\end{array}$ & $\begin{array}{c}\text { BCa 95\% } \\
\text { Confidence } \\
\text { Interval }\end{array}$ \\
\hline $\begin{array}{l}\text { Motivation in } \\
\text { Learning English }\end{array}$ & $\mathbf{N}$ & Sig. (1-tailed) & Bias & Lower & Upper \\
\hline $\begin{array}{l}\text { Pearson } \\
\text { Correlation }\end{array}$ & Intrinsic & 39 & -.385 & .005 & -.644 & -.103 \\
\hline & $\begin{array}{l}\text { Learning } \\
\text { Situations }\end{array}$ & 39 & -.685 & -.001 & -.828 & -.491 \\
& $\begin{array}{l}\text { Social } \\
\text { Development }\end{array}$ & 39 & -.421 & .014 & -.744 & -.017 \\
& $\begin{array}{l}\text { Informative } \\
\text { Medium }\end{array}$ & 39 & -.073 & $.005^{c}$ & $-.479^{\mathrm{c}}$ & $.275^{\mathrm{c}}$ \\
\hline
\end{tabular}




\begin{tabular}{lccccc}
\hline Individual & 39 & -.240 & -.002 & -.584 & .125 \\
$\begin{array}{l}\text { Development } \\
\text { Immediate Need }\end{array}$ & 39 & -.244 & $.008^{\mathrm{d}}$ & $-.565^{\mathrm{d}}$ & $.187^{\mathrm{d}}$ \\
\hline
\end{tabular}

a. Unless otherwise noted, bootstrap results are based on 2000 bootstrap samplesa

c. Based on 1998 samples $\mathrm{c}$

d. Based on 1917 samples

Table 3.3 shows that there is a significant negative correlation between the anxiety on self - confidence in speaking English and students' motivation in learning English language. That means, when there is an improvement in the motivation in learning English, there is a decrease in the anxiety in self-confidence in learning English. In particular, there is a strong (negative) correlation between learning situation and the anxiety on self-confidence in speaking English $(r=-.685)$. There is a moderate (negative) correlation between the social development and the self-confidence in speaking English $(r=-.421)$. And, there is a weak relationship between self - confidence in speaking English and intrinsic motivation $(r=-.385)$, individual development $(r=-.240)$, and immediate need $(r=-.244)$. A very weak (negligible) correlation has been found between informative medium and the self-confidence in speaking English $(r=$ -.073). Supporting the data is the identified absence of anxious feeling in different types of anxiety like speaking in English among the 170 male and female tertiary students in Pakistan (Waseem and Jibeen, 2013).

Table 3.4. Relationship between the General Anxiety about English Class and students' motivation in learning English language

\begin{tabular}{|c|c|c|c|}
\hline $\begin{array}{r}\text { ssessed Language } \\
\text { Anxiety }\end{array}$ & $\begin{array}{c}\text { General } \\
\text { Anxiety about } \\
\text { English Class }\end{array}$ & $\begin{array}{c}\text { Bootstrap for } \\
\text { Pearson } \\
\text { Correlation }\end{array}$ & $\begin{array}{l}\text { BCa 95\% } \\
\text { Confidence } \\
\text { Interval }\end{array}$ \\
\hline
\end{tabular}

\begin{tabular}{llccccc} 
& $\begin{array}{l}\text { Motivation in } \\
\text { Learning English }\end{array}$ & $\mathbf{N}$ & Sig. (1-tailed) & Bias & Lower & Upper \\
\hline $\begin{array}{l}\text { Pearson } \\
\text { Correlation }\end{array}$ & Intrinsic & 39 & -.304 & .005 & -.536 & -.022 \\
\cline { 2 - 5 } & $\begin{array}{l}\text { Learning } \\
\text { Situations }\end{array}$ & 39 & -.690 & .004 & -.836 & -.525 \\
& $\begin{array}{l}\text { Social } \\
\text { Development }\end{array}$ & 39 & -.320 & .004 & -.638 & .041 \\
& $\begin{array}{l}\text { Informative } \\
\text { Medium }\end{array}$ & 39 & -.026 & $-.007^{\mathrm{d}}$ & $-.464^{\mathrm{d}}$ & $.337^{\mathrm{d}}$ \\
& $\begin{array}{l}\text { Individual } \\
\text { Development }\end{array}$ & 39 & -.179 & -.009 & -.534 & .197 \\
\hline & $\begin{array}{l}\text { Immediate Need } \\
\text { Immen }\end{array}$ & 39 & -.177 & $.000^{\mathrm{e}}$ & $-.488^{\mathrm{e}}$ & $.238^{\mathrm{e}}$ \\
\hline
\end{tabular}

a. Unless otherwise noted, bootstrap results are based on 2000 bootstrap samplesa

d. Based on 1917 samples $_{d}$

e. Based on 1999 samplese

Table 3.4 shows that there is a significant negative correlation between the general anxiety about English class and students' motivation in learning English language. This tells us that when there is an improvement in the motivation in learning English language; there is 
a decrease in the general anxiety about English class. In particular, there is a strong (negative) correlation between learning situation and the general anxiety about English class $(r=-.690)$. There is a weak (negative) correlation between the general anxiety about English class and intrinsic motivation $(r=-.304)$ and social development $(r=-.320)$. A very weak (negligible) correlation has been found between the general anxiety about English class and informative medium $(r=-.026)$, individual development $(r=-.179)$ and immediate need $(r=-.177)$. Different studies show different relation of these variables; for instance, Tsai and Chang's (2013) identified little effect of anxiety to motivation depending on the participants' level of language proficiency and this is evident highly among those learners in intermediate level. At any rate, it was stated that in order to lessen anxiety and to increase learners' motivation, it is but necessary that affective kind of classroom environment must be attended by displaying comfort, cooperation, and constructive feedback, among others which start from the initiative of the teachers in their instructions and instructional tools.

Table 4. Summary of the relationship between the Assessed Language Anxiety and students' motivation in learning English language

\begin{tabular}{|c|c|c|c|c|}
\hline & $\begin{array}{r}\text { Assessed Language } \\
\text { Anxiety }\end{array}$ & $\begin{array}{r}\text { Speech Anxiety } \\
\text { and Negative } \\
\text { Evaluation }\end{array}$ & $\begin{array}{r}\text { Self - Confidence } \\
\text { in Speaking } \\
\text { English }\end{array}$ & $\begin{array}{r}\text { General Anxiety } \\
\text { about English } \\
\text { Class }\end{array}$ \\
\hline & Relationship & $\begin{array}{r}\text { positive } \\
\text { correlation }\end{array}$ & $\begin{array}{r}\text { negative } \\
\text { correlation }\end{array}$ & $\begin{array}{r}\text { negative } \\
\text { correlation }\end{array}$ \\
\hline \multirow{6}{*}{$\begin{array}{l}\text { Students' } \\
\text { motivation in } \\
\text { learning } \\
\text { English } \\
\text { language }\end{array}$} & Intrinsic & Weak & Weak & Weak \\
\hline & Learning Situations & Strong & Strong & Strong \\
\hline & Social Development & Weak & Moderate & Weak \\
\hline & Informative Medium & Very weak & Very weak & Very weak \\
\hline & $\begin{array}{l}\text { Individual } \\
\text { Development }\end{array}$ & Very weak & Weak & Very weak \\
\hline & Immediate Need & Very weak & Weak & Very weak \\
\hline
\end{tabular}

Summary of the two significant affective variables is presented in Table 4 where Learning Situations is the only item that shows strong relationship between language anxiety and students' motivation; hence, it shows a greater impact to the language anxiety of the students. Contrary to that, Informative medium and individual development have a negligible impact to language anxiety (except that they have a weak/little effect on the anxiety level of confidence in speaking English), while Intrinsic and social development has a weak/little effect on the language anxiety (except that social development has a moderate effect on the anxiety level of self-confidence in speaking English).

Table 5. Model Summary

\begin{tabular}{|c|c|c|c|c|c|c|c|c|c|c|}
\hline Model & $\mathbf{R}$ & $\begin{array}{c}\mathbf{R} \\
\text { Square }\end{array}$ & $\begin{array}{c}\text { Adjusted R } \\
\text { Square }\end{array}$ & $\begin{array}{c}\text { Std. Error } \\
\text { of the } \\
\text { Estimate }\end{array}$ & $\begin{array}{c}\text { R Square } \\
\text { Change }\end{array}$ & $\begin{array}{c}\text { Cha } \\
\text { F } \\
\text { Change }\end{array}$ & $\begin{array}{l}\text { e Statis } \\
\text { df1 }\end{array}$ & $\begin{array}{l}\text { cs } \\
\text { df2 }\end{array}$ & $\begin{array}{c}\text { Sig. F } \\
\text { Change }\end{array}$ & $\begin{array}{l}\text { Durbin- } \\
\text { Watson }\end{array}$ \\
\hline 1 & $.671^{\mathrm{a}}$ & .450 & .347 & 4.22539 & .450 & 4.359 & 6 & 32 & .003 & 1.645 \\
\hline
\end{tabular}




\begin{tabular}{lllllllllll}
2 & $.759^{\mathrm{a}}$ & .577 & .497 & 2.15882 & .577 & 7.268 & 6 & 32 & .000 & 1.860 \\
\hline 3 & $.721^{\mathrm{a}}$ & .520 & .430 & 2.94075 & .520 & 5.786 & 6 & 32 & .000 & 1.489 \\
\hline
\end{tabular}

a. Predictors: (Constant), Immediate Need, Intrinsic, Learning Situations, Social Development, Informative Medium, Individual Development

b. Dependent Variable (Model 1): Speech Anxiety And Negative Evaluation

c. Dependent Variable (Model 2): Anxiety in Self - Confidence in Speaking English

d. Dependent Variable (Model 3): General Anxiety about English Class

The $R=.671$ (Model 1), $R=.759$ (Model 2), and $R=.721$ (Model 3) shown in Table 5 show a strong level of prediction using the students' motivation in learning English language to predict the students' assessed language anxiety, Cohen (1988). The $\mathrm{R}^{2}$ value of .450 in Model 1 implies that $45 \%$ of the variance in the speech anxiety and negative evaluation can be explained by the students' motivation in learning English language. Model 2 and 3 suggest that $57.7 \%$ and $52 \%$ of the variance in the self-confidence in speaking English and general anxiety about English class, respectively, can be explained by the students' motivation in learning English language.

Table 6. ANOVA

\begin{tabular}{|c|c|c|c|c|c|c|}
\hline Model & & $\begin{array}{c}\text { Sum of } \\
\text { Squares }\end{array}$ & Df & Mean Square & $\mathbf{F}$ & Sig. \\
\hline \multirow[t]{3}{*}{1} & Regression & 466.983 & 6 & 77.831 & 4.359 & $.003^{\mathrm{d}}$ \\
\hline & Residual & 571.325 & 32 & 17.854 & & \\
\hline & Total & 1038.308 & 38 & & & \\
\hline \multirow[t]{3}{*}{2} & Regression & 203.223 & 6 & 33.871 & 7.268 & $.000^{\mathrm{d}}$ \\
\hline & Residual & 149.136 & 32 & 4.660 & & \\
\hline & Total & 352.359 & 38 & & & \\
\hline \multirow[t]{3}{*}{3} & Regression & 300.237 & 6 & 50.040 & 5.786 & $.000^{\mathrm{d}}$ \\
\hline & Residual & 276.737 & 32 & 8.648 & & \\
\hline & Total & 576.974 & 38 & & & \\
\hline
\end{tabular}

a. $\quad$ Dependent Variable (Model 1): Speech Anxiety And Negative Evaluation

b. Dependent Variable (Model 2): Anxiety in Self - Confidence in Speaking English

c. Dependent Variable (Model 3): General Anxiety about English Class

d. Predictors: (Constant), Immediate Need, Intrinsic, Learning Situations, Social Development, Informative Medium, Individual Development

Furthermore, the F-value in the ANOVA table as shown in Table 6 show that the students' motivation in learning English language is statistically significant to predict the speech anxiety and negative evaluation (Model 1), $F(6,32)=4.359, p<.05$, self -confidence in speaking English (Model 2), $F(6,32)=7.268, p<.05$, and general anxiety about English class (Model 3), $F(6,32)=5.786, p<.05$.

Table 7. Bootstrap Results for the Coefficients of Model 1, 2, and 3

Bootstrap $^{\text {a }}$

BCa $95 \%$ Confidence Interval

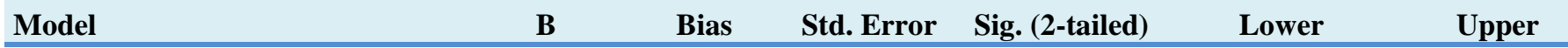


Relationship between Anxiety in Second Language Learning and Motivation Orientation: The Case of Young Filipino Learners

\begin{tabular}{|c|c|c|c|c|c|c|c|}
\hline \multirow[t]{7}{*}{1} & (Constant) & -4.367 & $.786^{\mathrm{b}}$ & $2.878^{\mathrm{b}}$ & $.044^{\mathrm{b}}$ & $-8.117^{b}$ & $7.858^{\mathrm{b}}$ \\
\hline & Intrinsic & .545 & $-.224^{b}$ & $.715^{\mathrm{b}}$ & $.325^{\mathrm{b}}$ & $-.601^{b}$ & $1.093^{\mathrm{b}}$ \\
\hline & Learning Situations & 2.326 & $-.006^{\mathrm{b}}$ & $.853^{\mathrm{b}}$ & $.020^{\mathrm{b}}$ & $.508^{\mathrm{b}}$ & $3.991^{\mathrm{b}}$ \\
\hline & Social Development & .875 & $.022^{\mathrm{b}}$ & $.839^{\mathrm{b}}$ & $.315^{\mathrm{b}}$ & $-.834^{\mathrm{b}}$ & $2.634^{\mathrm{b}}$ \\
\hline & Informative Medium & -.809 & $-.041^{\mathrm{b}}$ & $1.459^{\mathrm{b}}$ & $.403^{\mathrm{b}}$ & $-2.650^{b}$ & $1.104^{\mathrm{b}}$ \\
\hline & Individual Development & -.475 & $.228^{\mathrm{b}}$ & $1.326^{\mathrm{b}}$ & $.640^{\mathrm{b}}$ & $-3.289^{b}$ & $3.211^{\mathrm{b}}$ \\
\hline & Immediate Need & .820 & $-.565^{\mathrm{b}}$ & $3.396^{\mathrm{b}}$ & $.719^{b}$ & $-9.331^{b}$ & $5.541^{\mathrm{b}}$ \\
\hline \multirow[t]{7}{*}{2} & (Constant) & 1.933 & $-.219^{\mathrm{c}}$ & $1.451^{\mathrm{c}}$ & $.107^{\mathrm{c}}$ & $-1.146^{\mathrm{c}}$ & $3.750^{c}$ \\
\hline & Intrinsic & -.437 & $.053^{\mathrm{c}}$ & $.435^{\mathrm{c}}$ & $.255^{\mathrm{c}}$ & $-1.110^{\mathrm{c}}$ & $.567^{\mathrm{c}}$ \\
\hline & Learning Situations & -1.290 & $-.039^{c}$ & $.555^{\mathrm{c}}$ & $.043^{\mathrm{c}}$ & $-2.296^{\mathrm{c}}$ & $-.328^{\mathrm{c}}$ \\
\hline & Social Development & -.695 & $.000^{c}$ & $.473^{\mathrm{c}}$ & $.176^{\mathrm{c}}$ & $-1.586^{c}$ & $.167^{\mathrm{c}}$ \\
\hline & Informative Medium & 1.023 & $.034^{\mathrm{c}}$ & $.977^{\mathrm{c}}$ & $.175^{\mathrm{c}}$ & $-1.320^{c}$ & $3.150^{\mathrm{c}}$ \\
\hline & Individual Development & .358 & $-.044^{c}$ & $.776^{\mathrm{c}}$ & $.569^{\mathrm{c}}$ & $-1.297^{c}$ & $1.796^{\mathrm{c}}$ \\
\hline & Immediate Need & -1.870 & $.085^{\mathrm{c}}$ & $1.631^{\mathrm{c}}$ & $.128^{c}$ & $-4.341^{\mathrm{c}, \mathrm{d}}$ & $2.136^{\mathrm{c}}$ \\
\hline \multirow[t]{7}{*}{3} & (Constant) & 3.589 & $-.359^{\mathrm{e}}$ & $1.550^{\mathrm{e}}$ & $.009^{\mathrm{e}}$ & $.657^{\mathrm{e}}$ & $5.285^{\mathrm{e}}$ \\
\hline & Intrinsic & -.170 & $.108^{\mathrm{e}}$ & $.440^{\mathrm{e}}$ & $.682^{\mathrm{e}}$ & $-1.395^{\mathrm{e}}$ & $1.276^{\mathrm{e}}$ \\
\hline & Learning Situations & -2.079 & $-.043^{\mathrm{e}}$ & $.548^{\mathrm{e}}$ & $.002^{\mathrm{e}}$ & $-2.970^{\mathrm{e}}$ & $-1.177^{\mathrm{e}}$ \\
\hline & Social Development & -.517 & $-.067^{\mathrm{e}}$ & $.610^{\mathrm{e}}$ & $.407^{\mathrm{e}}$ & $-1.682^{\mathrm{e}}$ & $.474^{\mathrm{e}}$ \\
\hline & Informative Medium & .867 & $-.184^{\mathrm{e}}$ & $1.133^{\mathrm{e}}$ & $.269^{\mathrm{e}}$ & $-1.491^{\mathrm{e}}$ & $2.095^{\mathrm{e}}$ \\
\hline & Individual Development & .330 & $.072^{\mathrm{e}}$ & $.982^{\mathrm{e}}$ & $.669^{\mathrm{e}}$ & $-1.890^{\mathrm{e}}$ & $3.084^{\mathrm{e}}$ \\
\hline & Immediate Need & -1.428 & $.144^{\mathrm{e}}$ & $2.099^{\mathrm{e}}$ & $.324^{\mathrm{e}}$ & $-4.641^{e}$ & $3.443^{\mathrm{e}}$ \\
\hline
\end{tabular}

a. Unless otherwise noted, bootstrap results are based on 2000 bootstrap samples

b. Based on 1883 samples

c. Based on 1904 samples

d. Some results could not be computed from jackknife samples, so this confidence interval is computed by the percentile method rather than the BCa method.

e. Based on 1905 samples

f. Dependent Variable: Model 1 (Speech Anxiety And Negative Evaluation); Model 2 (Anxiety in Self-Confidence in Speaking English);

Model 3 (General Anxiety About English Class)

Table 7 shows that among the motivation types, only learning situations are considered to be the predictor of the students' assessed language anxiety $(p<.05)$ where:

The value $\mathrm{p}=.020$ under Sig column of Model 1 indicates that only the variable learning situations is considered the predictor of speech anxiety and negative evaluation. Hence, learning situations provide or explain a unique variance in speech anxiety and negative evaluation. Likewise, the value $\mathrm{p}=.043$ under Sig column of Model 2 indicates that only the variable learning situations is considered a predictor of anxiety in self-confidence in speaking English. Hence, it can be stated that learning situations provide or explain a unique variance in anxiety in self-confidence in speaking English. Finally, the value $p=.002$ under Sig column of Model 3 indicates that only the variable learning situations is considered a predictor of anxiety in General anxiety in English Class. Hence, we can say that learning situations provide or explain a unique variance in General anxiety in English class. 


\section{CONCLUSION}

Language anxiety and motivation have been proven in many studies as important constructs in learning both the second and foreign language. The previous, which is considered to be detrimental in providing encouraging learning behaviour in the acquisition of the second language, is identified through its type: speaking or communication anxiety, fear of negative evaluation and self-confidence in speaking English. The latter, which provides a positive atmosphere in the furtherance of interest in learning the second language, has been classified into intrinsic, immediate, learning situation, social responsibility, individual development and information medium. Each of them plays significant role in building an even high motivation on the part of the learners. Looking at how anxiety works among the respondents, it was found out that they do not have anxious feelings on speech anxiety and negative evaluation and speech anxiety and self-confidence in speaking English, but general anxiety in English class exists. These results were supported highly by the language motivation as all factors were identified to be influential in building motivated learning system especially in terms of intrinsic motivation and individual development.

Likewise, the relationship of the respondents' anxiety in terms of speech and negative evaluation, self-confidence and general anxiety and what motivates the young learners in learning English as reflected on motivation types was also measured. It was found out that there is a strong correlation between speech anxiety and negative evaluation and students' motivation. In terms of anxiety on self-confidence in speaking English and students' motivation, it was proven that there is a significant negative correlation emphasizing that an increase of motivation in learning the language is the decrease of their anxiety. Similarly, a significant negative correlation is also evident between the general anxiety about English class and students' motivation. Results show that while the learners of English as a second language are motivated in all its types with the absence of anxiety in learning except the general anxiety in English class, it is still recommended that classroom teachers sustain that positive drive in ESL class by preparing more dynamic and engaging tasks where students can maximize learning. Hence, this study would tell that while motivation is highly evident, anxiety may take place in case English class is not properly planned and managed. To this end, future studies may be conducted among young learners to provide wider literature using more variables, such as age group, to explore further how language anxiety and motivation serve the learning of the second language.

\section{REFERENCES}

Alico, J.C. (2015). Exploring English language anxiety: The case of pre-university students from minority tribes. ELK Asia Pacific Journal of Social Sciences, 2(1). DOI: 10.16962/EAPJSS/issn.2394-9392/2014.

Dy, J. C. \& Muñoz, A. M. S. (2017). Motivation and beliefs of learners of Chinese as a foreign language. International Conference on Applied Linguistics and Language Education. Manila: De La Salle University.

Elashhhab, S. (2020). Motivational teaching strategies within Saudi University EFL classrooms: How to improve students' achievement? International Journal of Language and Literary Studies, 2(1), 124-141. DOI: 10.36892/ijlls.v2i1.173.

Gardner, R.C., Lalonde, R.N. Moorcroft, R. \& Evers, F.T. (1987). Second language attrition: The role of motivation and use. Journal of Language and Social Psychology, 6(1), 29-47.

Gopang, I. B., Bughio, F. A. \& Pathan, H (2015). Investigating foreign language learning anxiety 
among students learning English in a Public Sector University, Pakistan. The Malaysian Online Journal of Educational Science 2015, 3(4), 27-37.

Hashwani, M. S. (2008). Students' attitudes, motivation and anxiety towards English language learning. Institute for Educational Development (Karachi), Aga Khan University, 120-144.

Hidayati, T. (2018). Student language anxiety in learning English: Examining non-English major students in rural area. IJELTAL (Indonesian Journal of English Language Teaching and Applied Linguistics), 2(2), 95-113.

Jain, Y. \& Sidhu, G.K. (2013). Relationship between anxiety, attitude and motivation of tertiary students in learning English as a second language. Procedia-Social and Behavioral Sciences, 90, 114-123.

Jin, L., Jiang, C, Zhang, J., Yuan, Y., Liang, X \& Xie, Q. (2014). Motivations and expectations of English language learning among primary school children and parents in China. London: British Council, 1-33.

Jurisevic, M. \& Pizorn, K. (2013). Young foreign language learners' motivation - A Slovenian experience. Porta Linguarum 19, 179-198.

Khodadady, B. \& Khajavy G. H. (2013). Exploring the role of anxiety and motivation in foreign language achievement: A structural equation modeling approach. Porta Linguarum 20, 269286.

Kormos, J. \& Cziser, K. (2008). Age-related differences in the motivation of learning English as a foreign language: Attitudes, selves, and motivated learning behavior. Language Learning: A Journal of Research in Language Studies, 58(2), 327-355.

Lian Wong, M. S. (2012). Language anxiety, motivation to learn and pedagogical preferences: The case of Malaysian pre-service teachers of English. ELTED, 15. Winter 2012.

Liu, H. (2012). Understanding EFL undergraduate anxiety in relation to motivation, autonomy, and language proficiency. Electronic Journal of Foreign Language Teaching, 9(1), 123-139.

Liu, H. \& Cheng, S. (2014). Assessing language anxiety in EFL students with varying degrees of motivation. Electronic Journal of Foreign Language Teaching, 11(2), 285-299.

Liu, H. \& Chen, W. (2015). A comparative study of foreign language anxiety and motivation of academic and vocational-track high school students. English Language Teaching, 8(3), 193204.

Lovato, C. (2011). Motivation in second language acquisition - Gardner's socio-educational model. Noveno Simposio de Ensino de Graduacao: Ambiente e sustentabilidade. Retrieved from http://www.unimep.br/phpg/mostraacademica /anais/9mostra/4/443.pdf.

Lucas, R. I., Miraflores, E. \& Go, D. (2011). English language learning anxiety among foreign language learners in the Philippines. Philippine ESL Journal, 7, 94-119.

Mahadi, T. S. T. \& Jafari, S. M. (2012). Motivation, its types, and its impact in language learning. International Journal of Business and Social Science, 3(24) (Special Issue - December 2012).

Mamhot, A. M. A., Martin, M. H. V. \& Masangya, E. M. (2013). A comparative study on the language anxiety of ESL and EFL learners. Philippine ESL Journal, 10, 200-231. 
Nicholson, S. J. (2013). Influencing motivation in the foreign language classroom. Journal of International Education Research (Third Quarter 2013), 9(3), 277-286.

Nunan, D. (2011). Second language teaching and learning. Pasig City, Philippines: Cencage Learning Asia Pte. Ltd.

Ozturk, K. (2014). Students' attitudes and motivation for learning English at Dokuz Eylul University School of Foreign Languages. Education Research and Reviews, 9(12), 376-386.

Wimolmas, R. (2013). A survey of motivation in English language learning of first year undergraduate students at Sirindhorn International Institute of Technology. Thailand: Thammasat University.

Shinge, M. (2005). Interplay among anxiety, motivation, and autonomu in second language learners of French: A quantitative and qualitative study. University of Florida, Florida, USA. Retrieved from http://etd.fcla.edu/UF/UFE0011620/shinge_m.pdf.

Snowman, J. \& Biehler, R. (2003). Psychology applied to teaching $\left(10^{\text {th }}\right.$ ed.). Boston, MA:

Houghton Mifflin Company.

Tahernezhad, E., Behjat, F. \& Kargar, A. A. (2014). The relationship between language learning anxiety and language learning motivation among Iranian intermediate EFL learners. International Journal of Language and Linguistics, 2(6-1), 35-48.

Thomas Baby, K. (2020). Application of mobile phone as a motivational tool in the ESP classrooms of Dhofar University. International Journal and Literary Studies, 2(1), 81-89. DOI: 10.36892/ijlls.v2i1.116

Tsai, C.C. \& Chang, I.C. (2013). The study on motivation and anxiety of English learning of students at a Taiwan Technical University. International Journal of English Language Teaching, 1(1), 24-41.

Waseem, F. \& Jibeen, (2013). Anxiety amongst learners of English as a second language: An examination of motivational patterns in the Pakistani context. International Journal of Humanities and Social Sciences, 3(16) (Special Issue - August 2013), 174-184.

Wu, K. H. (2010). The relationship between language learners' anxiety and learning strategy in the CLT classrooms. International Education Studies, 3(1), 174-191.

Yihong, G., Yuan, Z. \& Ying, C. \& Yan, Z. (2007). Relationship between English learning motivation types and self-identity changes among Chinese students. TESOL Quarterly, 41(1).

$\mathrm{Yu}, \mathrm{Z}$. (2016). The analysis about the factors of silence in college English classroom. Studies in Literature and Language, 12(5), 105-110. doi: 10.3968/8402.

Zhang, R. \& Zhong, J. (2016). The hindrance of doubt: Causes of language anxiety. International Journal of English Linguistics, 2(3). Canadian Center of Science and Education, 22-33.

Zheng, Y. (2008). Anxiety and second/foreign language learning revisited. Canadian Journal for New Scholars in Education, 1(1). 


\section{AUTHORS'BIOS}

Juland Dayo Salayo teaches English and Research at the University of Santo Tomas Manila. He is currently writing his dissertation for his Doctor of Philosophy in English Education degree at the Philippine Normal University - Manila. His research interests include Critical Pedagogy, Sociolinguistics, Stylistics Analysis, Second Language Acquisition and Discourse Analysis.

Dr. Arceli M. Amarles is a graduate faculty handling applied linguistics and English language education specialization courses at the College of Graduate Studies and Teacher Education (CGSTER) of the Philippine Normal University (PNU), Manila - The National Center for Teacher Education (NCTE). She earned her PhD in Applied Linguistics at De La Salle University, Manila. She was the Director of Membership and Secretary of the Linguistic Society of the Philippines (LSP). Moreover, she serves as Adviser of the PNU Applied Linguistics and English Language Education Society (PALELES), a programbased graduate student organization for graduate students specializing in Applied Linguistics, and English Language Education at PNU. Her research interests focus on Academic Writing, Discourse Analysis, Sociolinguistics, World Englishes and Mother Tongue-Based Multilingual Education (MTB-MLE). 
